Part of Journal of Research of the National Bureau of Standards, Volume 18, January 1937

\title{
ANODIC COATING OF MAGNESIUM ALLOYS
}

\author{
By R. W. Buzzard and J. H. Wilson
}

\section{ABSTRACT}

Magnesium alloys may be anodized in a bath of sodium phosphate, $\left(\mathrm{NaH}_{2} \mathrm{PO}_{4}\right.$.$\left.\mathrm{H}_{2} \mathrm{O}\right)$ and sodium dichromate, $\left(\mathrm{Na}_{2} \mathrm{Cr}_{2} \mathrm{O}_{7} \cdot 2 \mathrm{H}_{2} \mathrm{O}\right)$. The film obtained combines both corrosion-resistance and paint-holding properties, without serious change of dimensions of the treated piece, even on machined surfaces.

\section{CONTENTS}

I. Introduction

II. Bath composition

III. Procedure

IV. Bath control

V. Properties of anodic film 85

VI. Summary

VII. Selected references

\section{INTRODUCTION}

Magnesium alloys, because of their low density and relatively high strength and ductility, have many advantages for use in aircraft. Noteworthy disadvantages, however, are their marked susceptibility to corrosive attack under saline conditions and the low degree of adherence of protective coatings to their surfaces. Numerous attempts have been made to improve their behavior by treating the surface so as to produce a protective film. A solution containing $1.5 \mathrm{lb} / \mathrm{gal}$ or $180 \mathrm{~g}$ /liter of $\mathrm{Na}_{2} \mathrm{Cr}_{2} \mathrm{O}_{7} .2 \mathrm{H}_{2} \mathrm{O}$ and $1.5 \mathrm{pt} / \mathrm{gal}$ or $190 \mathrm{ml} /$ liter of $\mathrm{HNO}_{3}$, sp gr 1.42, and known as the "chrome pickle" [1] " that was described by Winston and his associates [2] has yielded satisfactory results for many purposes. The surface condition produced by this treatment serves both as a retardant of corrosion and as a good paint base. However, this treatment cannot be satisfactorily applied to dimensioned machined surfaces, as it materially reduces the cross section. The alkaline chromate treatment [3] developed by Sutton and LeBrocq [4] can be used on machined surfaces but, according to tests by the present authors, it has not been found to give corrosion protection equivalent to that of the chrome-pickle treatment.

The remarkable success attained with the anodic oxidation or socalled "anodizing" of aluminum and its alloys prompted attempts to develop a similar treatment for magnesium, even though previous efforts to develop a satisfactory electrolytic treatment had not been very successful. A process has recently been perfected which combines in large measure the advantages of the chrome-pickle and the alkaline chromate treatments.

\footnotetext{
1 Numbers in brackets refer to literature references at the end of the paper.
} 


\section{BATH COMPOSITION}

Numerous experiments led to the selection of a bath containing about 10 percent of sodium dichromate, $\left(\mathrm{Na}_{2} \mathrm{Cr}_{2} \mathrm{O}_{7} \cdot 2 \mathrm{H}_{2} \mathrm{O}\right)$, and 2 to 5 percent of monosodium phosphate, $\left(\mathrm{NaH}_{2} \mathrm{PO}_{4} \cdot \mathrm{H}_{2} \mathrm{O}\right)$.

\section{PROCEDURE}

All parts must be carefully cleaned before being anodized. Electrolytic cleaning has been found very satisfactory. For example, the specimen is made the cathode for at least 3 minutes at $90^{\circ} \mathrm{C}\left(194^{\circ} \mathrm{F}\right)$ in a bath containing

Sodium carbonate (soda ash) $\left(\mathrm{Na}_{2} \mathrm{CO}_{3}\right)_{--}-4 \mathrm{oz} / \mathrm{gal}(30 \mathrm{~g} /$ liter);

Trisodium phosphate $\left(\mathrm{Na}_{3} \mathrm{PO}_{4} .12 \mathrm{H}_{2} \mathrm{O}_{\ldots} \ldots . .4 \mathrm{oz} / \mathrm{gal}(30 \mathrm{~g} /\right.$ liter $)$.



FIGURE 1.-Relative value of anodic films as paint bases.

A sufficient potential (usually 4 to 6 volts) is applied to produce a vigorous evolution of hydrogen around the specimen being cleaned. Steel plates are used as anodes.

The cleaned metal is then made the anode in the anodizing bath, in which the cathode is steel and a sufficient voltage is applied to produce a current density of 5 to 10 amperes per square foot of anode surface. The time necessary to produce a satisfactory coating is dependent on the composition of the alloy, the temperature of the bath, and the current density used; at $50^{\circ} \mathrm{C}$ it varies between 30 and 60 minutes.

Satisfactory results with most of the commercial alloys of magnesium have been obtained in this laboratory with a bath of the above composition, operated over a wide range of temperature and of current density. The permissible maximum current density is limited by the occurrence of pitting on the anode. As might be expected, as the 
current density is increased, the time required to produce a good coating is lowered considerably. Satisfactory surface films have been obtained on an alloy of the magnesium-aluminum class $(4.0 \% \mathrm{Al}$ and $0.3 \% \mathrm{Mn}$ ) with current densities from 5 to 100 amperes per square foot and with temperatures from 30 to $80^{\circ} \mathrm{C}$ (86 to $\left.176^{\circ} \mathrm{F}\right)$. The favorable conditions are more restricted for alloys of the magnesiummanganese type. A lower current density, preferably less than 10 amperes per square foot, was found necessary with an alloy having the nominal composition of $1.5 \% \mathrm{Mn}$ and $98.5 \% \mathrm{Mg}$.

A satisfactory coating is smooth and adherent and does not flake on a sheet when bent at an angle of $90^{\circ}$. The color varies with the composition of the alloy treated, from a dirty green to a shiny black. The higher the aluminum content of the alloy, the darker is the film.

\section{BATH CONTROL}

Satisfactory operation of this bath depends on the maintenance of proper hydrogen-ion concentration $(\mathrm{pH})$. For the phosphatedichromate bath described above, the $\mathrm{pH}$ should be maintained between 4.0 and 4.8. During operation of the bath, magnesium is dissolved and the $\mathrm{pH}$ rises. Phosphoric acid must then be added to restore the initial $\mathrm{pH}$. A glass electrode has been found most satisfactory for measuring the $\mathrm{pH}$.

Magnesium phosphate is only sparingly soluble in the phosphatedichromate solution. As magnesium dissolves during the use of the bath, the saturation point of magnesium phosphate is reached, and a precipitate of this substance forms, which removes phosphate ion from the bath. The addition of the amount of phosphoric acid required to maintain the desired $\mathrm{pH}$ of the solution is not usually sufficient to maintain the necessary concentration of the phosphate ion. Additional sodium phosphate, in amounts determined by analysis of the bath, must therefore be added. The dichromate concentration changes very slowly with use, and an occasional analysis will indicate when more dichromate is necessary.

\section{PROPERTIES OF ANODIC FILM}

Corrosion tests by the salt-spray method have shown the anodic films to be equal in corrosion resistance to the surface coatings produced by chemical treatment. The method used was to determine the change in tensile properties, especially elongation, of strips of sheet material that were machined to tensile-bar dimensions after exposure to the salt-spray test. Salt-spray tests were made with a 20 -percent solution of $\mathrm{NaCl}$ at $35^{\circ} \mathrm{C}$, on a magnesium alloy $(4.0 \mathrm{Al}$, $0.3 \mathrm{Mn}$ ), in sheet form 0.060 inch thick and having an average initial elongation of 12.4 percent. Exposure to salt spray for 5 days caused a loss of 63 percent in elongation on specimens that had been given the chrome-pickle treatment, and of 44 percent on anodized specimens. The chrome-pickle treatment was carried out in a fresh solution to assure the production of a film of the best quality. 
TABLE 1.-Loss in elongation of cast tensile bars of magnesium-aluminum alloys (percentage of initial elongation) $(6.0 \mathrm{Al}, 0.2 \mathrm{Mn}, 3.0 \mathrm{Zn})$ after 10 days in $20-$ percent $\mathrm{NaCl}$ spray at $35^{\circ} \mathrm{C}$

[Initial elongation 7.8 percent]

\begin{tabular}{|c|c|c|}
\hline Bar & Surface preparation & $\begin{array}{l}\text { Loss of } \\
\text { elongation }\end{array}$ \\
\hline $\begin{array}{l}1 \\
2 \\
3 \\
4 \\
5 \\
6 \\
8\end{array}$ & $\begin{array}{l}\text { Bare } \\
\text { Anrome-pickle-without previous cleaning } \\
\text { Alkaline chromate-caustic cleaning } \\
\text { Chrome-pickle-caustic cleaning } \\
\text { Alkaline chromate-electrolytic cleaning } \\
\text { Chrome-pickle-electrolytic cleaning } \\
\text { Anodic-electrolytic cleaning }\end{array}$ & $\begin{array}{r}\text { Percent } \\
\text { 32. } 0 \\
22.0 \\
10.0 \\
20.0 \\
4.0 \\
10.0 \\
23.0 \\
0\end{array}$ \\
\hline
\end{tabular}

Cast tensile bars of magnesium alloy $(6.0 \mathrm{Al}, 0.2 \mathrm{Mn}, 3.0 \mathrm{Zn})$ with an average initial elongation of 7.8 percent, were tested in the same manner for 10 days. In table 1 are shown the percentage losses in elongation for bars treated under different conditions. The anodic coating on bar 8 showed no corrosion on visual examination and no loss of elongation in the tensile test.

Salt-spray tests have shown that the anodic film is equal to chromepickled surfaces as a paint base. Specimens of magnesium-aluminum alloy (4 percent of Al, 0.3 percent of $\mathrm{Mn}$ ) with two coats of aluminumpigmented spar varnish applied to the bare surface, and also those painted after various surface treatments such as the fluoride [5] Parko (a phosphate dip), selenious acid (6) and chrome-pickle, showed failure on visual examination. Anodized specimens showed no failure in a similar test for the same periods.

For a comparison of chrome-pickled surfaces with anodic surfaces as paint bases, two sets of specimens were prepared, one of which was anodized and the other was chrome-pickled. ${ }^{2}$ Both were then coated as follows:

One coat of zinc chromate primer was applied and baked for 1 hour at $225^{\circ} \mathrm{F}$; one coat of surfacer was applied and baked for 1 hour at $225^{\circ} \mathrm{F}$, and two successive coats of black baking enamel were applied and baked for 1 hour at $200^{\circ} \mathrm{F}$.

After 3 weeks of exposure to salt spray the specimens were tested in tension. The chrome-pickled specimens suffered an average loss of 41 percent of the initial elongation, while the anodized bars showed a loss of only 21 percent.

Magnesium-aluminum alloy sheet that was weighed before and after the anodic treatment showed a loss in weight of the order of $0.1 \mathrm{~g} / \mathrm{dm}^{2}$, which is about 1 percent of the weight. The measured loss in thickness did not, however, exceed 0.0001 inch, which is much less than that observed on chrome-pickled specimens.

\section{SUMMARY}

Magnesium alloys can be coated by an anodic process. The films obtained combine corrosion-resistance and paint-holding properties, and the process causes no appreciable change of dimensions of the treated piece, even on machined surfaces.

${ }^{2}$ Chrome-pickled and painted by courtesy of the Dow Chemical Co., Midland, Mich. 


\section{SELECTED REFERENCES}

[1] Chrome-pickle treatment of magnesium base alloys. Bureau of Aeronautics, Navy Department Spec. M-303, Pt. 1, February 6, 1936.

[2] Surface preparation and painting of magnesium alloys. A. W. Winston, J. B. Reid, and W. H. Gross. Ind. Eng. Chem. 2\%, 1333 (1935).

[3] Chemical treatment no. 3-Magnesium Base Alloys. Bureau of Aeronautics, Navy Department Spec. M-303, Pt. 2 (June 1, 1936).

[4] The protection of magnesium alloys against corrosion. H. Sutton and L. F. LeBrocq. J. Inst. Metals 5\%, 199 (1935).

[5] P. Prier. U. S. Patent 1957354. (May 1, 1934.)

[6] G. D. Bengough and L. Whitby. British Patent 378916 (May 1, 1934.)

[7] Magnesium alioys in aeroplanes. E. R. Gadd. Aircraft Eng. (England) $\boldsymbol{y}$, no. 82 (December 1935).

[8] The corrosion of elektron alloy AM503 by leaded fuels. G. D. Bengough and L. Whitby. J. Royal Aero. Soc. no. 300, 39 (December 1935).

[9] Dowmetal. The Dow Chemical Co., Midland, Mich. (1935).

[10] Light alloy for aeronautical purposes with special reference to magnesium alloys. L. Aitchison. J. Royal Aero. Soc. no. 281, 38, 382 (May 1934).

[11] Magnesium alloy protection by selenium and other coating processes. G. D. Bengough and L. Whitby, J. Inst. Metals 48, no. 1, 147 (1932); J. Soc. Chem. Ind. 50, 835 (1931).

Washington, October 19, 1936. 